\title{
Factors Influencing Fourth-Year Pharmacy Students' Decisions to Pursue a Hospital Pharmacy Residency
}

\author{
Sébastien Dupuis, Alexis Martel, Taha Arfa, Joannah Valma, David R Williamson, and Marc M Perreault
}

\begin{abstract}
Background: The Canadian Society of Hospital Pharmacists promotes the recruitment of residency-trained pharmacists for work in hospitals and related health care settings. However, Quebec hospitals are still hiring non-residency trained pharmacists, in part because of a severe shortage of hospital pharmacists. To date, no studies have examined the factors influencing the career choices of fourth-year pharmacy students in Canada.

Objectives: To identify motivating factors and barriers influencing students' decision to pursue a hospital pharmacy residency.

Methods: All 186 fourth-year students in the Faculty of Pharmacy, Université de Montréal, were invited by e-mail to participate in a validated and institutionally approved survey that was available online between March and May 2014.

Results: Of the 138 respondents who returned a completed survey $(74 \%$ response rate), 36 (26\%) planned to apply for a hospital pharmacy residency. Those planning to apply for a residency were older $(p=0.037)$ and had more hospital work experience ( $36 \%$ versus $3 \%, p<0.001)$ than those not planning to apply. The most important motivators for pursuing a residency were potential gains in knowledge (reported by $88 \%$ of respondents, whether or not they were planning to pursue a residency), experience $(80 \%)$, and self-confidence $(62 \%)$. The most frequently reported barriers were recognition that a hospital pharmacy residency is a highly demanding program (65\%), having work available upon graduation from the undergraduate program $(43 \%)$, and financial obligations (34\%). Hospital experiential rotations influenced, either positively or negatively, $23(72 \%)$ of the 32 students who changed their decision to pursue or not pursue residency training over the course of their studies.

Conclusions: The potential gain in knowledge and experience acquired through residency, the fact that it is considered a highly demanding program, and having work available upon graduation from undergraduate studies were the most influential factors in fourth-year pharmacy students' decision of whether to pursue a hospital pharmacy residency.
\end{abstract}

Keywords: pharmacy education, residency training, pharmacy student, career choice

Can J Hosp Pharm. 2016;69(3):209-15

\section{RÉSUMÉ}

Contexte : La Société canadienne des pharmaciens d'hôpitaux encourage les établissements de santé à embaucher des pharmaciens qui ont fait une résidence. Or, les hôpitaux du Québec continuent d'embaucher des pharmaciens dénués de cette formation, entre autres à cause d'une importante pénurie de pharmaciens hospitaliers. À ce jour, aucune étude n’a examiné les facteurs qui influencent les choix de carrière des étudiants en quatrième année de pharmacie au Canada.

Objectifs : Découvrir les facteurs qui motivent les étudiants à faire une résidence en pharmacie d'hôpital et les facteurs qui les en dissuadent.

Méthodes : L'ensemble des 186 étudiants en quatrième année à la Faculté de pharmacie de l'Université de Montréal ont été invités par courriel à participer à un sondage validé, approuvé par l'établissement, qui était disponible en ligne entre mars et mai 2014.

Résultats : Parmi les 138 répondants ayant rempli et retourné le sondage (taux de réponse de $74 \%), 36(26 \%)$ avaient l'intention de s'inscrire à la résidence en pharmacie d'hôpital. Ces derniers étaient plus âgés $(p=0,037)$ et possédaient une plus grande expérience de travail en hôpital (36\% contre $3 \%, p<0,001)$ que ceux qui n'envisageaient pas de s'inscrire à la résidence. Les facteurs qui motivaient le plus tous les répondants (dont ceux qui ne planifiaient pas faire une résidence) à entreprendre une résidence étaient la possibilité : d'acquérir les connaissances (88\%), de gagner de l'expérience (80\%) et d'augmenter la confiance en soi (62\%). Les facteurs qui dissuadaient le plus souvent l'ensemble des répondants étaient : la conviction que la résidence en pharmacie d'hôpital est un programme très exigeant $(65 \%)$, l'accès à un travail dès qu'ils obtiennent le diplôme de premier cycle (43\%) et les obligations financières (34\%). Les stages en milieu hospitalier ont influencé, positivement ou négativement, $23(72 \%)$ des 32 étudiants qui ont changé d'idée quant à la poursuite ou non d'une résidence pendant leurs études.

Conclusions : La possibilité d'acquérir des connaissances et de l'expérience grâce à la résidence, le fait que le programme soit considéré comme très exigeant et l'accès à un emploi dès l'obtention du diplôme de premier cycle : ces facteurs influençaient le plus le choix des étudiants en quatrième année pour ce qui est d'entreprendre ou non une résidence en pharmacie d'hôpital.

Mots clés : enseignement de la pharmacie, résidence, étudiant en pharmacie, choix de carrière 


\section{INTRODUCTION}

A dvances in therapeutics and an aging population are important factors contributing to increased complexity of patients' pharmacotherapy regimens. As of 2006, about half of Canadians over 65 years of age were taking 5 or more medications. ${ }^{1}$ Moreover, it is anticipated that by 2030 nearly one-quarter of the Canadian population will be 65 years or older. ${ }^{2}$ Pharmacist-led interventions have been shown to have a positive impact on multiple patient outcomes in various hospital settings. ${ }^{3-5}$ In Canada, undergraduate pharmacy programs (BPharm or entrylevel PharmD) tend to focus on the management of chronic illnesses, so it is residency programs that prepare and train pharmacists for the more complex cases and acute illnesses observed in the hospital setting. ${ }^{6}$ In Quebec, a residency is obtained through a master's degree in advanced pharmacotherapy and consists of one full-time semester of courses followed by 12 months of training in a hospital or related health care setting.

The Canadian Society of Hospital Pharmacists (CSHP) set a goal that, by 2015, 100\% of new pharmacists entering practice in hospitals and related health care settings will have completed a residency accredited by the Canadian Hospital Pharmacy Residency Board (now known as the Canadian Pharmacy Residency Board). ${ }^{7}$ Currently, there remains a shortage of residency-trained hospital pharmacists in the province of Quebec, which has persisted for the past decade. ${ }^{8}$ Reasons for this shortage include the additional education required, as well as the noncompetitive salaries of hospital pharmacists. ${ }^{6}$ Facing this shortage, some hospitals are hiring non-residency trained pharmacists. As of 2014, 75\% of newly employed hospital pharmacists in Quebec had Board-accredited residency training.?

Understanding the factors that influence fourth-year pharmacy students in their career choices would be helpful to better promote residency programs and target those likely to apply. Data on such factors are available for the United States. ${ }^{10-14}$ However, in Canada, such an evaluation has not been performed. Therefore, a survey was designed and conducted to identify motivators and barriers influencing fourth-year pharmacy students in their decision of whether to pursue hospital pharmacy residency training.

\section{METHODS}

\section{Study Design}

A cross-sectional survey of fourth-year pharmacy students at one Quebec university was conducted from March to May 2014. The study was approved by the Université de Montréal Faculty of Pharmacy Research Committee and the Université de Montréal Health Research Ethics Committee (Centre éthique de la recherche en santé). Signed informed consent was waived, as participants were deemed to have provided implicit informed consent by agreeing to respond to the survey after reading the cover letter.

\section{Survey Development and Distribution}

Survey items were generated from a literature search, motivational letters from former applicants to the residency program, and focus groups held with third- and fourth-year pharmacy students. The number of survey items was reduced to 24 through additional focus groups and input from the investigator team (the director of the residency program, a hospital pharmacist consultant, and a fourth-year pharmacy student). The survey was divided into 4 domains: demographic characteristics, career choices, respondent's vision of the pharmacy profession, and master's program in advanced pharmacotherapy. All items were multiple-choice questions with nominal or ordinal responses; some questions had the option for a respondent to add open comments. The survey, which was available in French only, can be found in Appendix 1 (see www.cjhp-online.ca/index.php/ cjhp/issue/view/115/showToc). A group of 14 fourth-year pharmacy students (class of 2009-2013) pilot-tested the survey and assessed item appropriateness and comprehensiveness, and the survey was revised on the basis of their comments. Reliability was tested by distributing the survey to 13 fourth-year pharmacy students on 2 different occasions, separated by a 2 -week interval; their responses showed excellent correlation (weighted kappa = 0.75). ${ }^{15}$ The survey was converted to an online format using SurveyMonkey software (SurveyMonkey Inc, Palo Alto, California), and a link to the survey was distributed by e-mail to all 186 fourth-year students in the Université de Montreal Faculty of Pharmacy on March 5, 2014; participants then responded to the survey online. Reminder e-mails were sent twice, at monthly intervals after initial delivery of the survey. Students had until mid-May 2014 to respond to the survey. Of note, the deadline for applications for a hospital pharmacy residency was mid-March 2014, and by May 2014, all of the fourth-year students had been exposed to 16 weeks of experiential community practice and 12 weeks of experiential hospital practice.

\section{Data Analysis}

Surveys with more than $6(25 \%)$ unanswered questions and those that did not provide information on the respondent's career choice were deemed incomplete and were discarded. Data for categorical variables are presented as proportions. For items related to decisional factors, answers categorized as having a high or very high impact were combined for greater practicality. After identifying which factors had the greatest impact across all respondents, the responses were stratified into 2 groups for comparison: students who planned to pursue residency training and those not planning to do so. The decision to pursue residency training was defined as having applied for the master's program in advanced pharmacotherapy in Quebec or a residency elsewhere in Canada (i.e., any other Canadian Hospital Pharmacy Residency Board-accredited residency). The other group consisted of those who wanted to work in a community 
pharmacy or a hospital without formal residency training. Results were compared using $\chi^{2}$ tests. Significant $p$ values were defined as those less than 0.05 . All statistical analyses were performed using SPSS software (IBM SPSS Statistics for Windows, version 21.0, IBM Corp, Armonk, New York).

\section{RESULTS}

Of 186 surveys delivered, 142 (76\%) were returned (Figure 1 ). The majority of surveys (88 [62\%]) were answered in May. Four incomplete surveys were discarded, which left a total of 138 respondents, corresponding to an analyzable response rate of $74 \%$. A total of 36 respondents (26\%) anticipated applying for a pharmacy residency. Of the remaining 102 respondents $(74 \%)$ who did not plan to apply for a residency, a majority $(n=96)$ planned to work exclusively in the community pharmacy setting.

Most respondents were women in their early 20s (Table 1). Respondents pursuing residency training were significantly older than those not applying $(p=0.037)$. Nearly half of the respondents $(47 \%)$ had been admitted directly into pharmacy school

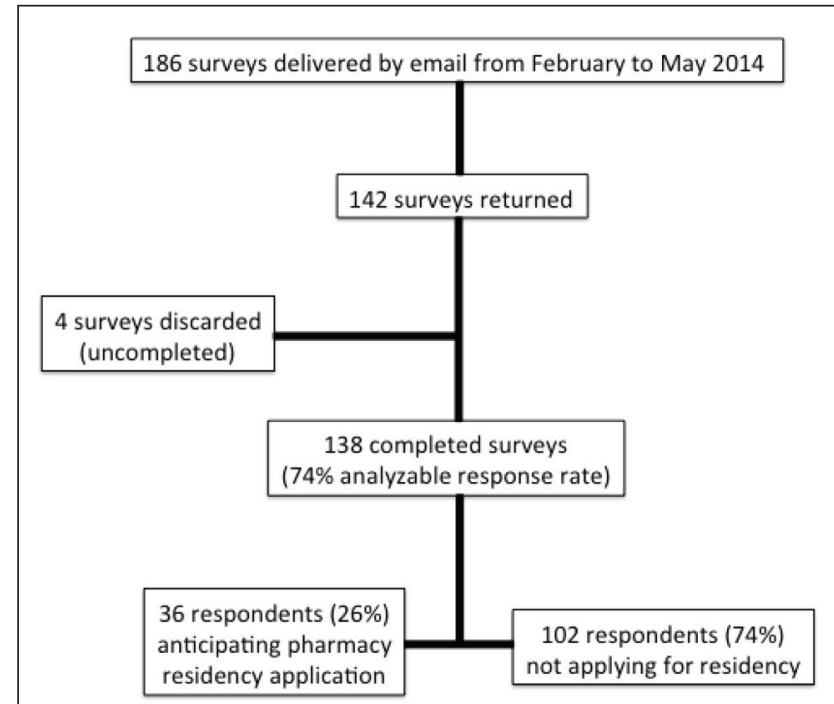

Figure 1. Flow chart depicting administration of the survey.

Table 1. Demographic Characteristics of Respondents to a Survey about Residency Plans

\begin{tabular}{|c|c|c|c|c|}
\hline \multirow[b]{2}{*}{ Characteristic } & \multicolumn{3}{|c|}{ Group; No. (\%) of Respondents } & \multirow[b]{2}{*}{$p$ Value* } \\
\hline & All Respondents & No Residency & Residency & \\
\hline Sex & $n=138$ & $n=102$ & $n=36$ & 0.76 \\
\hline Male & $45(33)$ & $34(33)$ & $11(31)$ & \\
\hline Female & $93(67)$ & $68(67)$ & $25(69)$ & \\
\hline Age (years) & $n=137$ & $n=101$ & $n=36$ & 0.037 \\
\hline $22-24$ & $96(70)$ & $76(75)$ & $20(56)$ & \\
\hline $25-27$ & $32(23)$ & $18(18)$ & $14(39)$ & \\
\hline$\geq 28$ & $9(7)$ & $7(7)$ & $2(6)$ & \\
\hline Ethnicity & $n=137$ & $n=102$ & $n=35$ & 0.43 \\
\hline White & $107(78)$ & $79(77)$ & $28(80)$ & \\
\hline Arabic & 7 (5) & $6(6)$ & $1(3)$ & \\
\hline Asian & $18(13)$ & $12(12)$ & $6(17)$ & \\
\hline Other & $5(4)$ & $5 \quad(5)$ & 0 & \\
\hline University GPA† & $n=136$ & $n=101$ & $n=35$ & 0.38 \\
\hline$\geq 4.0$ & $9(7)$ & $8(8)$ & 1 (3) & \\
\hline $3.8-3.9$ & $26(19)$ & $21(21)$ & $5(14)$ & \\
\hline $3.4-3.7$ & $60(44)$ & $40(40)$ & $20(57)$ & \\
\hline $3.1-3.3$ & $33(24)$ & $25(25)$ & $8(23)$ & \\
\hline$\leq 3.0$ & $8(6)$ & $7 \quad(7)$ & $1(3)$ & \\
\hline Preadmission studies & $n=138$ & $n=102$ & $n=36$ & 0.06 \\
\hline College degree & $65(47)$ & $53(52)$ & $12(33)$ & \\
\hline Uncompleted baccalaureate & $41(30)$ & $30(29)$ & $11(31)$ & \\
\hline Completed baccalaureate & $30(22)$ & $17(17)$ & $13(36)$ & \\
\hline Postgraduate studies & $2(1)$ & $2(2)$ & 0 & \\
\hline $\begin{array}{l}\text { Work experience during } \\
\text { pharmacy school }\end{array}$ & $n=138$ & $n=102$ & $n=36$ & $<0.001$ \\
\hline Retail pharmacy & $102(74)$ & $86(84)$ & $16(44)$ & \\
\hline Hospital & $16(12)$ & $3(3)$ & $13(36)$ & \\
\hline Does not work & $13(9)$ & $10(10)$ & $3(8)$ & \\
\hline Other & $7 \quad(5)$ & $3(3)$ & $4(11)$ & \\
\hline
\end{tabular}

GPA $=$ grade point average.

*Comparison between "no residency" and "residency" groups. These groups refer to whether or not the respondent was planning to apply to a residency.

tCanadian equivalents for GPA: A+ = 4.0 GPA, A = 3.9 GPA, A- = 3.7 GPA, B+ = 3.3 GPA, B = 3.0 GPA. 
after obtaining their 2-year postsecondary, preuniversity college degree (through one of Quebec's CEGEP colleges); the rest had been admitted directly from another university program. There was a trend for more residency applicants than nonapplicants to have completed an undergraduate program other than pharmacy before entering pharmacy school ( $36 \%$ versus $17 \%, p=0.06)$. A larger proportion of respondents pursuing a residency had prior work experience in a hospital during pharmacy school $(36 \%$ versus $3 \%, p<0.001)$. Sex, ethnicity, and university grade point average did not differ significantly between the 2 groups.

Among residency applicants, the 3 most important factors influencing the decision to pursue a residency were the potential gain in knowledge and experience ( $97 \%$ for each) and the potential gain in self-confidence (74\%) (Table 2). These 3 factors were also identified as being the most important by the nonapplicant group. Nonapplicants attributed significantly less importance to the following factors (relative to nonapplicants): gain in experience, recognizing residency as a prerequisite to work in hospital, being recognized as a specialist, and participation in a research project.

Overall, the most important barriers identified by respondents were recognition that residency is a highly demanding program (65\%), availability of work upon graduation (43\%), and financial obligations (34\%) (Table 3). Nonapplicants felt significantly less informed about residency, and more of them had work available upon graduation relative to applicants.

Seventy-three percent of the 138 respondents first received information about the residency program during their third or fourth year, but $62 \%$ believed that such information should be provided during the first 2 academic years. Thirty-two (23\%) of the respondents reported changing their career orientation during their fourth academic year: 19 respondents who were initially thinking about pursuing a residency ultimately decided not to do so, whereas the opposite scenario occurred for 13 respondents.
Overall, 24 respondents (17\%) were still unsure about their final career choice (community versus hospital). Among factors that influenced respondents to alter their decision during their fourth academic year, hospital experiential rotations (affecting 23 respondents [72\%]) and hospital pharmacy preceptors (affecting 20 respondents [63\%]) had the strongest influence. Work experience influenced the decision of $18(56 \%)$ of these respondents, and community pharmacy preceptors and community experiential rotations influenced 11 (34\%). These factors had a similar impact on the respondents who did not change their minds.

\section{DISCUSSION}

The current survey identified factors influencing fourth-year pharmacy students' decision of whether to pursue a hospital pharmacy residency. It also identified demographic differences between students who planned to pursue to residency and those who did not plan to do so.

The proportion of respondents who had completed an undergraduate degree before entering pharmacy school was greater among those who wanted to pursue a residency than among those not planning to do so; those planning to pursue a residency were also significantly older. It might be anticipated that older students who have already completed a degree might want to join the workforce, rather than applying for a residency, as they probably have more financial obligations, but this survey showed the contrary. These students may be putting more value on continuing their education and increasing their competency. In addition, the survey results confirmed that those planning to apply for residency had greater work experience in a hospital setting during pharmacy school, which demonstrates their interest in hospital practice at an early stage in their studies. No data were collected on the characteristics of students who did not respond the survey, and it remains possible that students

Table 2. Motivating Factors Influencing the Decision to Apply for a Residency

\begin{tabular}{|c|c|c|c|c|}
\hline \multirow[b]{2}{*}{$\begin{array}{l}\text { Motivating Factor with a } \\
\text { High Impact on Decision }\end{array}$} & \multicolumn{3}{|c|}{ Group; No. (\%) of Respondents* } & \multirow[b]{2}{*}{$p$ Valuet } \\
\hline & $\begin{array}{l}\text { All Respondents } \\
\quad(n=138)\end{array}$ & $\begin{array}{l}\text { No Residency } \\
(n=102)\end{array}$ & $\begin{array}{l}\text { Residency } \\
(n=36)\end{array}$ & \\
\hline Gain knowledge & $121(88)$ & $87(85)$ & $34(97)$ & 0.31 \\
\hline Gain experience & $109(80)$ & $75(74)$ & 34 (97) & 0.035 \\
\hline Gain self-confidence & $84(62)$ & $58(57)$ & $26(74)$ & 0.27 \\
\hline Prerequisite to working in hospital & $62(46)$ & $38(38)$ & $24(71)$ & 0.011 \\
\hline Scholarship available & $73(55)$ & $50(51)$ & $23(66)$ & 0.22 \\
\hline Being recognized as a specialist & $54(40)$ & $34(34)$ & $20(57)$ & 0.010 \\
\hline $\begin{array}{l}\text { Competitive advantage on } \\
\text { labour market }\end{array}$ & $45(33)$ & $30(30)$ & $15(43)$ & 0.25 \\
\hline Access to teaching positions & $46(34)$ & $32(32)$ & $14(40)$ & 0.25 \\
\hline Participate in a research project & $23(17)$ & $11(11)$ & $12(34)$ & 0.002 \\
\hline
\end{tabular}

*Some respondents did not provide a ranking of impact for every motivating factor. As such, some of the percentages were calculated using a smaller denominator than the sample size at the top of the column. tComparison between "no residency" and "residency" groups. These groups refer to whether or not the respondent was planning to apply to a residency. 
This single copy is for your personal, non-commercial use only.

For permission to reprint multiple copies or to order presentation-ready copies for distribution, contact CJHP at cjhpedit@cshp.ca

\section{Table 3. Barriers Influencing the Decision to Apply for a Residency}

\begin{tabular}{lcccc} 
& \multicolumn{3}{c}{ Group; No. (\%) of Respondents* } & \\
\cline { 2 - 4 } $\begin{array}{l}\text { Barrier with a High Impact } \\
\text { on Decision }\end{array}$ & $\begin{array}{c}\text { All Respondents } \\
(\mathbf{n = 1 3 8 )}\end{array}$ & $\begin{array}{c}\text { No Residency } \\
(\mathbf{n}=\mathbf{1 0 2})\end{array}$ & $\begin{array}{c}\text { Residency } \\
(\mathbf{n}=\mathbf{3 6})\end{array}$ & p Valuet \\
\hline Highly demanding program & $89(65)$ & $68(67)$ & $21(62)$ & 0.87 \\
Work available upon graduating & $60(43)$ & $52(51)$ & $8(23)$ & 0.001 \\
Financial obligations & $46(34)$ & $35(34)$ & $11(31)$ & 0.42 \\
Geographic remoteness & $39(29)$ & $29(29)$ & $10(29)$ & 0.73 \\
Family obligations & $28(20)$ & $25(25)$ & $3(9)$ & 0.13 \\
Feeling uninformed about residency & $28(20)$ & $24(24)$ & $4(11)$ & 0.002 \\
GPA below requirements $(<3.0)$ & $16(12)$ & $13(13)$ & $3(9)$ & 0.42 \\
\hline
\end{tabular}

GPA = grade point average.

* Some respondents did not provide a ranking of impact for every barrier. As such, some of the percentages were calculated using a smaller denominator than the sample size at the top of the column.

tComparison between "no residency" and "residency" groups. These groups refer to whether or not the respondent was planning to apply to a residency.

interested in residency training were more likely to answer the survey than those who were not interested, although the response rate minimizes this selection bias.

Potential gains in knowledge, experience, and selfconfidence are often reported as being among the most influential factors identified by respondents of comparable US surveys. ${ }^{10-12}$ Recognizing that working in a hospital requires additional training and expertise because of the complexity of the pharmacotherapy regimens of admitted patients might partially explain these responses. Students may feel that, without a residency, they do not have the appropriate skills to work in a hospital setting and they want to gain more knowledge and experience in pharmacotherapy and pathophysiology from the courses and experiential rotations that are part of the residency program. Differences between the groups in terms of factors with the greatest influence can be partly explained by nonapplicants' lack of interest in working in a hospital setting. Nonapplicants are probably comfortable with their training and do not feel the need to gain more experience to enter the job market in community practice. They may also be less interested in specialization, as they probably see themselves as general practitioners. It was also anticipated that this group would be less attracted by research projects, which typically are more common in institutional health care settings, and this was confirmed by the survey results.

Other significant factors identified by previous surveys have included the desire for specialized training, the understanding that residency is a prerequisite for certain jobs, and enhancement of self-confidence. ${ }^{10-12}$ In contrast to the results obtained here, increased competition in the labour market was also identified as an important factor in 2 previous surveys. ${ }^{11,13}$ During periods of staff shortage, health care managers may be tempted to hire new pharmacists, regardless of their residency training. However, as the shortage gradually subsides, competition may increase in importance, possibly favouring pharmacists with more specialized training that better addresses patients' health care needs. The possible future recognition of hospital pharmacy as a specialty might help to attract more students into residency training.
Respondents identified many benefits of residency training; however, significant barriers also exist. About two-thirds of respondents believed that residency programs are highly demanding. Such a workload is to be expected in the pursuit of graduate studies; however, it would be surprising for students to choose not to pursue residency training solely for that reason. Another important barrier relates to the community practice market, with the ready availability of community pharmacy jobs deterring potential candidates from applying to a residency program. However, as the shortage of community pharmacists subsides, future applications for residency positions may increase.

In contrast to the findings presented here, the presence of financial obligations was by far the most influential barrier preventing pursuit of a residency in the United States. ${ }^{12}$ High tuition fees in US universities likely play a greater role in the decision not to pursue a residency than is the case in Canada. Other significant barriers in the previous US study ${ }^{12}$ included having a job opportunity upon graduating and family obligations, at about the same proportions as observed in the survey presented here.

The promotion of residencies through information sessions during undergraduate studies may have a positive impact on students' career selection; however, the effect of this factor has not been consistent among studies. ${ }^{11,13,14}$ The current survey indicated that although feeling uninformed about residency was not considered an important barrier overall, there was still 1 student out of every 5 who felt uninformed. At the Université de Montréal, a general information session is presented every year to inform students about all potential career paths in pharmacy. In addition, third- and fourth-year pharmacy students are invited once yearly to a formal information session on hospital pharmacy residencies, and the slide presentation for this session is sent to all students via e-mail. The current survey results raise the issue of whether to include second-year students as well. Respondents who felt less well informed about residency were likely the ones who did not want to pursue their studies, which may also reflect a lack of interest in residency training from this group. 
It is of interest and concern that 1 of every 5 respondents was still unsure about career orientation at the time of completing this survey, which was distributed 3 to 4 months before graduation. The reasons for this uncertainty are unclear. Career uncertainty remained, despite the presentation and dissemination of information on career opportunities throughout the undergraduate program, including a 1-day event organized by the Association des pharmaciens d'établissements de santé (the Quebec association of hospital pharmacists) and the 2 faculties of pharmacy in the province, which focuses on demystifying hospital pharmacy practice and presenting the many roles played by such pharmacists. The timing of survey distribution, in early March, might have influenced the level of uncertainty; however, at that point, most respondents were in their last clinical rotation of the program. A majority of respondents answered during May, which is past the deadline for residency applications, at a point when nearly all of them had completed their clinical rotations.

Changes in career orientation during fourth-year experiential rotations were reported by a substantial number of respondents. These changes were highly influenced by either the hospital experiential rotations or directly by the hospital preceptors. Students having a positive experience probably tended to change in favour of residency, whereas those having a negative experience tended to orient themselves toward community practice.

To our knowledge, this is the first Canadian survey to collect information on factors influencing the decision to pursue a hospital pharmacy residency. It had an acceptable sample size and response rate. The good response rate (74\%) reflects the potential for fourth-year pharmacy students to apply for residency. It was not possible to determine whether survey respondents had actually applied for a residency, but because the survey was administered close to the application deadline, the potential for respondents to change their decision was small. Another limitation is that application to a residency program was used as a surrogate for eventually being hired in a health care setting, although it would be expected that the vast majority of residents will actually work in a health care setting after their training. The results presented are from a single cohort of students (2010-2014 academic program) at a single institution, which limits their generalizability. Students from other institutions and pharmacists coming from the job market who applied to our residency program were not included in the survey. Given differences in pharmacy undergraduate programs across Canadian provinces, it would be interesting to determine whether the survey results would be similar across all provinces.

\section{CONCLUSION}

This survey identified potential gains in knowledge and experience acquired through residency, the fact that a residency is considered a highly demanding program, and the availability of work upon graduation from undergraduate studies as the most influential factors in fourth-year pharmacy students' decision to pursue or not pursue a hospital pharmacy residency. Understanding the many factors that influence students will help in identifying ways to overcome some of the barriers and ways to better promote hospital pharmacy practice and residencies.

\section{References}

1. Bajcar JM, Wang L, Moineddin R, Nie JX, Tracy CS, Upshur RE. From pharmaco-therapy to pharmaco-prevention: trends in prescribing to older adults in Ontario, Canada, 1997-2006. BMC Fam Pract. 2010;11:75.

2. Population projections: Canada, the provinces and territories, 2013 to 2063. In: The daily. Ottawa (ON): Statistics Canada; 2014 Sep [cited 2015 Dec 10]. Available from: www.statcan.gc.ca/daily-quotidien/140917/ dq140917a-eng.htm

3. Bond CA, Raehl CL. Clinical pharmacy services, pharmacy staffing, and adverse drug reactions in United States hospitals. Pharmacotherapy. 2006; 26(6):735-47.

4. Bond CA, Raehl CL. Clinical pharmacy services, pharmacy staffing, and hospital mortality rates. Pharmacotherapy. 2007;27(4):481-93.

5. MacLaren R, Bond CA, Martin SJ, Fike D. Clinical and economic outcomes of involving pharmacists in the direct care of critically ill patients with infections. Crit Care Med. 2008;36(12):3184-9.

6. Position de l'APES sur l'embauche de pharmaciens diplômés du $1^{\text {er }}$ cycle universitaire en pharmacie dans les établissements de santé. Montréal (QC): Association des pharmaciens des établissements de santé du Québec; 2015 [cited 2015 Dec 10]. Available from: www.apesquebec.org/sites/default/files/ 20150930_position_embauche_pharm.pdf

7. Canadian hospital pharmacy 2015 (CSHP 2015): CSHP goals and objectives for pharmacy practice in hospitals and related healthcare settings to be achieved by 2015. Ottawa (ON): Canadian Society of Hospital Pharmacists; 2007 [updated 2008; cited 2014 Dec 12]. Available from: www.cshp.ca/ $\mathrm{dms} / \mathrm{dms} V$ iew/2_CSHP-2015-Goals-and-Objectives-Feb-25\%2707-wAppdx-rev-May\%2708.pdf

8. Portrait des effectifs en pharmacie dans les établissements de santé du Québec selon les données de l'enquête annuelle menée par l'A.P.E.S. auprès des chefs de département de pharmacie. Montréal (QC): Association des pharmaciens des établissements de santé du Québec; 2013 [cited 2014 Dec 12]. Available from: www.apesquebec.org/lapes/les-membres/penurie-de-pharmaciens-enetablissement-de-sante

9. Bornstein C. Chapter E: CSHP 2015. In: Bonnici A, Bornstein C, Bussières JF, Doucette D, Hall K, Jones R, et al., editors. Hospital pharmacy in Canada 2013/14 report. Eli Lilly; 2015 [cited 2015 Jul 7]. Available from: http://stage.lillyhospitalsurvey.ca/hpc2/content/2015_report/chapter_e\%20.pdf

10. Fit KE, Padiyara RS, Rabi SM, Burkiewicz JS. Factors influencing pursuit of residency training [letter]. Am J Health Syst Pharm. 2005;62(21):2226, 2235.

11. Jacobs TF, Manor SM. Effect of a seminar on pharmacy student attitudes toward residency training. Am J Health Syst Pharm. 2008;65(14):1358-62.

12. McCarthy BC Jr, Weber LM. Update on factors motivating pharmacy students to pursue residency and fellowship training. Am J Health Syst Pharm. 2013;70(16):1397-403.

13. Tai BW, Beardsley RS, Lebovitz LP. Significant factors that influence pharmacy students' decisions to pursue residencies [letter]. Am J Pharm Educ. 2011; 75(10):212.

14. Stover KR, Fleming LW, Riche DM, Sherman JJ, Bloodworth LS. Impact of a residency interest group on students applying for residency. Am J Pharm Educ. 2014;78(6):127.

15. Burns KE, Duffett M, Kho ME, Meade MO, Adhikari NK, SinuffT, et al.; ACADEMY Group. A guide for the design and conduct of self-administered surveys of clinicians. CMAJ. 2008;179(3):245-52.

Sébastien Dupuis, PharmD, MSc, is with the Faculte de pharmacie, Université de Montréal, and the Pharmacy Department, Hôpital du SacréCoeur de Montréal, Montréal, Quebec. 
Alexis Martel, PharmD, is with the Pharmacy Vandergoten and Zaccara, Saint-Eustache, Quebec

Taha Arfa, BPharm, MBA, is with the Faculté de pharmacie, Université de Montréal, Montréal, Quebec.

Joannah Valma, MSc, is with the Faculté de pharmacie, Université de Montréal, Montréal, Quebec.

David R Williamson, BPharm, MSc, PhD, BCPS, is with the Faculté de pharmacie, Université de Montréal, and the Pharmacy Department, Hôpital du Sacré-Coeur de Montréal, Montréal, Quebec.

Marc M Perreault, MSc, PharmD, BCPS, is with the Faculté de pharmacie, Université de Montréal, and the Pharmacy Department, McGill University Health Centre, Montréal, Quebec. He is also an Associate Editor with the Canadian Journal of Hospital Pharmacy.
Competing interests: None declared.

\section{Address correspondence to:}

Dr Marc M Perreault

Faculté de pharmacie

Université de Montréal

C. P. 6128 , succursale Centre-Ville

Montréal QC H3C 3J7

e-mail: marc.perreault@umontreal.ca

\section{Funding: None received.}

Acknowledgements: The authors wish to acknowledge the contribution of Johanne Vinet for literature search support provided to the research team during survey design and writing of the manuscript.

\section{Compounding: Guidelines for Pharmacies 2014}

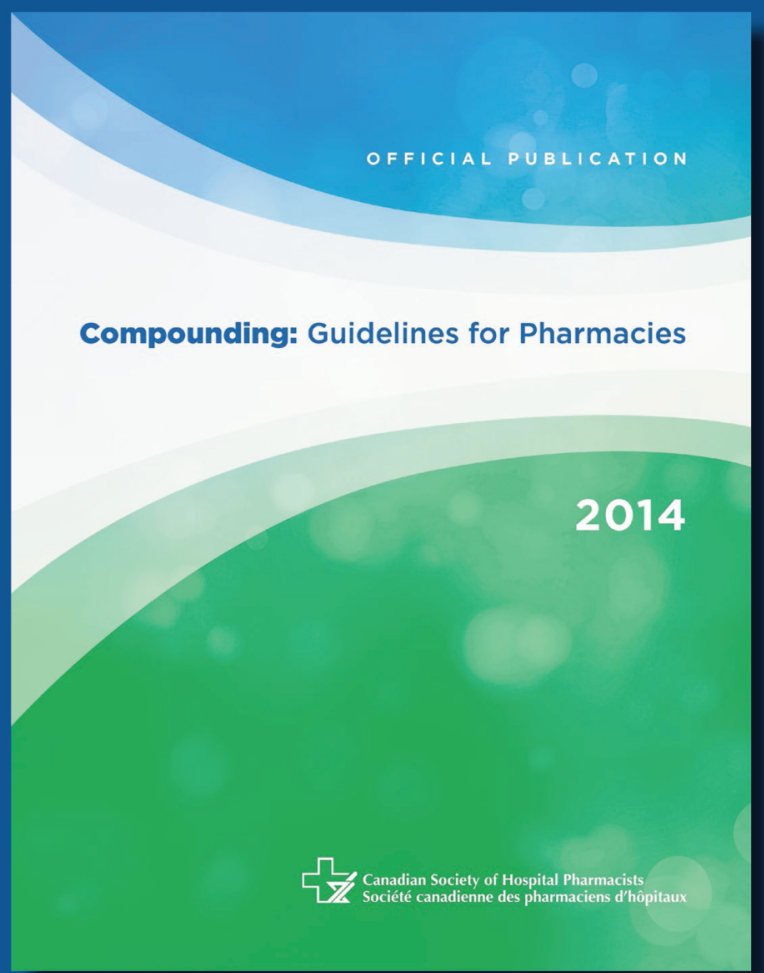

The Canadian Society of Hospital Pharmacists' comprehensive set of guidelines covers the compounding in pharmacies whenever compounded preparations are intended for human use, regardless of the route of administration or whether the preparation is related to research purposes. These guidelines also apply to the preparation of radiopharmaceuticals and other hazardous pharmaceuticals.

Find our order form here: http://www. cshp.ca/dms/dmsView/I CSHP.Publications-form-Jan2015.pdf

Contact the CSHP Publications Administrator for more information:

E: aiannaccio@cshp.ca

P: 6|3-736-9733 x:228 